\title{
First record on Loxosceles laeta (Nicolet, 1849) (Araneae, Sicariidae) in the West Zone of São Paulo City, São Paulo, Brazil, and considerations regarding its geographic distribution
}

\author{
Primeiro registro de Loxosceles laeta (Nicolet, 1849) (Araneae, Sicariidae) \\ na Zona Oeste do Município de São Paulo, São Paulo, Brasil, \\ e considerações sobre sua distribuição geográfica
}

\section{Rute Maria Gonçalves-de-Andrade ${ }^{1}$ and Denise Vilarinho Tambourgi ${ }^{1}$}

\begin{abstract}
Loxosceles laeta spiders were captured in the West zone of São Paulo City, this being the first record of the specie in this area. Since loxoscelism is an important public health problem in the South region of Brazil, it is necessary to investigate the presence of this spider in São Paulo City.
\end{abstract}

Key-words: Loxosceles laeta. Loxoscelism. geographic distribution.

Resumo Espécimens da aranha Loxosceles laeta foram capturados na zona Oeste do município de São Paulo, Por ser o loxosceloxoscelismo importante problema de saúde pública na região Sul do Brasil, é necessário investigar a presença dessa espécie na cidade de São Paulo.

Palavras-chaves: Loxosceles laeta. Loxoscelismo. Distribuição geográfica.

Loxoscelism is the clinical condition produced by the venom of spiders belonging to the genus Loxosceles, which can be observed as two well-defined clinical variants: cutaneous loxoscelism (CL) and systemic or viscerocutaneous loxoscelism (VCL) which occur in around $83.3 \%$ and $16.7 \%$ of the cases respectively ${ }^{10}$.

Pain, edema and liveloid plaque that develop later into a necrotic scar, are the predominant local manifestations in CL. In VCL, hematuria and hemoglobinuria are always observed, while jaundice, fever and sensorial involvement occur in most of the cases. Although systemic loxoscelism is less common than the cutaneous form, it is the main cause of death associated with Loxosceles envenomation. Most of the fatalities occur in children and are related to the South American species, L. laeta ${ }^{2}$.

Human cases of loxoscelism have been reported in diverse countries of various continents in temperate and tropical regions. One hundred Loxosceles species have been described: eighty-six in America, two in Asia (China) and twelve in Africa. Two species are cosmopolitan: L. rufescens (North American specie) and L. laeta (South American specie), both found in Europe and the latter also in Australia9.

In the anthropic environment Loxosceles' dispersion is highly facilitated because, as it is cryptozoic, it can shelter and proliferate among piles of bricks, wood and roof tiles, which also enables its transportation to other geographical areas.

Among South American species, L. laeta, possibly the most toxic of all the species, has the widest geographical distribution, a fact that can be associated to its resistance to long periods without food or water ${ }^{8}$. This characteristic contributes to its survival when transported for long distances. Furthermore, L. laeta presents significant reproductive potential: each female can produce up to fifteen egg sacs during its life $^{3}$ and each of these may contain from fifty to one hundred

1. Laboratório de Imuoquímica do Instituto Butantan, São Paulo, SP.

Address to: Dra Rute Maria Gonçalves de Andrade. Laboratório de Imunoquímica/Instituto Butantan. Av Vital Brazil 1500, Butantã 05503-900 São Paulo, SP, Brasil.

e-mail:rutemgdeandrade@butantan.gov.br

Recebido para publicação em 14/12/2002

Aceito em 26/5/2003 
and forty six eggs (Gonçalves-de-Andrade, data not published), with a high egg fertility index ${ }^{6}$.

According to Gerstch ${ }^{4}$, Loxosceles laeta is possibly an endemic species of the Southwest America, which has been introduced into the East of this continent and also into both North and Central America. In Brazil, it occupies urban and periurban ecotops predominantly in the South country region. Knowledge of the current geographic distribution of Loxosceles laeta is very important, considering the toxicity of its venom and the association of this specie with most of the fatal cases of loxoscelic envenoming reported in South America.

Loxosceles laeta spiders have been captured manually in the Hospital Psiquiátrico Pinel, localized on Raimundo Pereira de Magalhães Avenue, 5214, Pirituba District, West area, São Paulo, SP, Brazil. They were placed in round plastic pots $(9.5 \mathrm{~cm}$ diameter $\times 5.5 \mathrm{~cm}$ height) and are being kept in the Biotério de Criação de Aranhas Loxosceles of the Immunochemistry Laboratory, Butantan Institute.

Three males and one spiderling probably in the fourth instar were captured. A male was found inside one of the complex buildings; the other two were found in an open area under the construction, where it was possible to observe several L. laeta skins, as well as webs and egg sacs, whose eggs had already hatched and the spiderlings, dispersed. The spiderling has been captured in a deposit for disused material. Three females have also been observed, but were not captured as they were in a difficult location for collection. Several skins of L. laeta have been observed in construction sites of the park.

Loxosceles laeta belongs to Gertsch' laeta group, which includes another twenty-four species distributed in Central (Guatemala and Panama) and South America (Curacao, Trinidad, Venezuela, Colombia, Ecuador, Peru and Chile $)^{4}$. This is the largest species of the group and its presence has already been registered at heights from 200 up to $2340 \mathrm{~m}^{4}$. In North America, its presence has been well notified: there are records of $L$. laeta populations in Vancouver, Canada ${ }^{5}$ and in the United States, in Cambridge (Massachusetts) ${ }^{7}$, California (Los Angeles) ${ }^{11}$, Kansas $^{5}$ and, more recently, in Florida ${ }^{1}$. In Central America, it has been found in Guatemala and Belize and, in South America, in Brazil, Ecuador, Peru, Bolivia, Chile, Argentina and Uruguay. In addition to the Americas, L. laeta is also present in Finland and Australia ${ }^{5}$.

In Brazil, the presence of this specie has already been registered in the states of Paraíba, Minas Gerais (Riacho da Cruz), Rio de Janeiro (Barcelos), Paraná (Vale do Ribeira, Curitiba and Ponta Grossa), Santa Catarina and Rio Grande do Sul (Santo Angelo, Pelotas)4.

In the state of São Paulo, data of Gertsch ${ }^{4}$ show records of the species in the cities of Francisco Sodré, Cerqueira César, São Carlos, Pindamonhangaba and, in São Paulo city, in the neighborhood of Ipiranga, south city zone.

We have, recently, captured specimens of $L$. laeta in the State of São Paulo, in São Paulo City, west area, Pirituba District, in a public hospital. The hospital has an area of 77 square meters, 32 thousand of which are green areas. The spiders were captured inside buildings that belong to the hospital complex and in the external area.

The presence of Loxosceles laeta in several different environments and diverse heights and climate, associated with its high reproductive capacity ${ }^{3}{ }^{6}$, are characteristics that distinguish it as an eurioic specie, determining a high adaptability and, consequently, wide ecological valence.

This is the first record of $L$. laeta in this area of São Paulo City and stresses the necessity of studies investigating its population dynamics in order to prevent dispersion and the risk of human envenomation.

\section{REFERENCES}

1. Edwards GB. Chilean recluse, Loxosceles laeta (Nicolet) (Araneae: Sicariidae) in Florida. Pest Alert online at http:// www.doacs.state.fl.us/ pi/enpp/ento/loxoscel.html. 2002.

2. Futrell JM. Loxoscelism. American Journal of Medical Science 304:261-267, 1992

3. Galiano ME, Hall M. Datos adicionales sobre el ciclo vital de Loxosceles laeta (Nicolet, 1849) (Araneae) Physis, 32:277-288, 1973.

4. Gertsch WJ. The spider genus Loxosceles in South America (Araneae: Scytodidae). Bulletin of American Museum of Natural History 136:119-183, 1967.

5. Gertsch WJ, Ennik F. The spider genus Loxosceles in North America, Central America, and the West Indies (Araneae, Loxoscelidae). Bulletin of American Museum of Natural History 175: 264-360, 1983

6. Gonçalves-de-Andrade RM, Lourenço WR, Tambourgi DV. Comparison of the fertility between Loxosceles intermedia and Loxosceles laeta spiders. The Journal of Arachnology 28: $245-247,2000$

7. Levi H, Spielman A. The biology and control of the South American brown spider Loxosceles laeta (Nicolet) in a North American focus. American Journal of Tropical Medicine and Hygiene 13:132-136, 1964.

8. Lowrie DC. Starvation longevity of Loxosceles laeta (Nicolet) (Araneae). Entomology News 91: 130-132, 1980.

9. Platnick NI. The world spider catalog, version 3.0. American Museum of Natural History, online at http://research.amnh.org/ entomology/spiders/catalog81-87/index.html. 2003.

10. Schenone $H$, Saavedra T, Rojas A, Villarroel F. Loxoscelism in Chile. Epidemiologic, clinical and experimental studies. Revista do Instituto de Medicina Tropical de São Paulo 31:403-415, 1989.

11. Waldron WG. Loxosceles laeta (Nicolet) an introduced species in Los Angeles County. Bulletin of Entomological Society of America 15:377-379, 1969 